\title{
Social wasp (Hymenoptera: Vespidae) beer trapping in Finland 2008-2012: a German surprise
}

\author{
Jouni Sorvari
}

\begin{abstract}
Sorvari, J. 2013: Social wasp (Hymenoptera: Vespidae) beer trapping in Finland 2008-2012: a German surprise. — Entomol. Fennica 24: 156-164.

Beer trapping has been carried out annually in the summer in south western Finland (Turku) from 2008 to 2012 inclusive. In 2012, an additional trapping programme was conducted in southern (Helsinki), central (Kuopio) and northern (Kevo) Finland, which also included another trapping location in the south western (Turku) region. The traps were always presented for seven days in each location. While the median wasp Dolichovespula media (Retzius, 1783) was present in all locations, the common wasp Vespula vulgaris Linnaeus, 1758 was found in five out of six locations ( 20 traps per site). The Kevo individual represents the northernmost record for the median wasp species. The German wasp Vespula germanica (Fabricius, 1793) was surprisingly common in south western and southern Finland. Vespula germanica has a short history of occurrence in Finland and seems to have shifted its range northwards, possibly due to climate change. Some common species of the genus Dolichovespula Rohwer, 1916 were likely underrepresented, because they are not very attracted by beer.
\end{abstract}

\begin{abstract}
J. Sorvari, Department of Biology, Section of Ecology, FI-20014 University of Turku, Finland, and presently: Department of Environmental Science, University of Eastern Finland, P.O. Box 1627, FI-70211 Kuopio, Finland; E-mail: jouni.sorvari@uef.fi
\end{abstract}

Received 4 February 2013, accepted 26 February 2013

\section{Introduction}

Social wasps collect protein food for their growing larvae and carbohydrate food for their own nutrition. Nectar from flowers, aphid honey-dew, sap and fermenting fruits are natural carbohydrate sources for social wasps (e.g., Witt 2009). Beer has been shown to be an effective trapping substance in social wasp monitoring studies (Dvořák 2007, Dvořák \& Roberts 2007, Roberts \& Dvořák 2008). However, it also seems to have some limitations since not all social wasp species are equally attracted by fermented products or carbohydrates (Seath 1999, Wegner \& Jordan 2005, Dvořák \& Landolt 2006).
The German wasp Vespula germanica (Fabricius, 1793) is a central and southern European species with a natural range between North Africa in the south and $60^{\circ} \mathrm{N}$ in Eurasia, extending to $64^{\circ} \mathrm{N}$ in Sweden (Kurzenko 1982, Witt 2009, Douwes et al. 2012). In Finland, the known nesting population was limited to the Alland Islands until 1998 (Söderman 1999; for location of Åland Islands see Fig. 1).

There have been only three observations of $V$. germanica in continental Finland prior to 2000; all of which were non-nesting queens (Pekkarinen \& Hulden 1995, Johansson \& Pekkarinen 2000). However, those queens that migrated to continental Finland have been unsuc- 


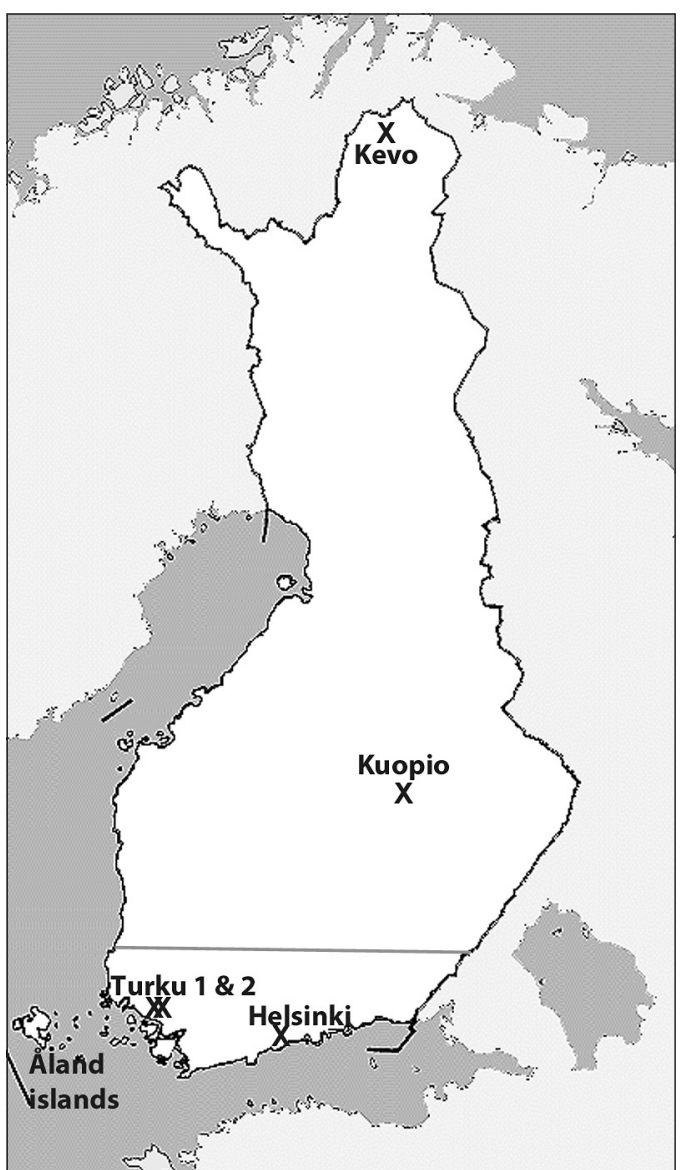

Fig. 1. The trapping locations. Turku 1 was studied 2008-2012, the others in 2012. The line across southern Finland indicates the northern limit of observations of Vespula germanica workers in Finland: city of Rau$m a$ in the west and Imatra in the east. The Âland Islands were the only region colonized by $V$. germanica in Finland before year 2001.

cessful in founding colonies. For example, in March 1996 a newly deceased queen was found on the snow from Turku (Johansson \& Pekkarinen 2000) which is located in the southwest corner of continental Finland (see Fig. 1). It seems that the early emergence from hibernation has been the likely limiting factor for successful colonisation in northern areas (Johansson \& Pekkarinen 2000).

Although $V$. germanica was caught in Åland Islands and along the Baltic coast in Russia, Estonia, Latvia and Lithuania, it was not captured in continental Finland during an extensive yellow trap monitoring project in 1997-1998 (Söderman 1999). Similarly, it was not caught in continental Finland in yellow and white traps in 1996 (Söderman et al. 1997).

Since 2001 there have been several observations of $V$. germanica workers in southern Finland, particularly around the greater Helsinki area (i.e. cities of Helsinki, Espoo and Vantaa; R. Molini, J. Paukkunen, J. Pöyry, I. Teräs \& S. Väänänen, pers. comm.). One breeding colony was found in Turku in the summer of 2005 (Eeva et al. 2006). Earlier in the same period another colony was also found in Turku, located under the stairs of a grocery store (Sorvari unpubl.). However, it was exterminated by the management due to the nuisance caused by the high number of foragers.

It seems that since the abovementioned yellow trap monitoring projects (Söderman et al. 1997, Söderman 1999), V. germanica has become reasonably common in continental Finland, at least in the most southern part of the country. Nevertheless, studies monitoring its recent abundance have been lacking. Since beer has been shown to attract $V$. germanica (Dvořák 2007, Roberts \& Dvořák 2008), it seems that beer trapping is an ideal method for monitoring.

My study questions were threefold. First, what species compositions are attracted to beer in different parts of Finland? Second, what kind of species variation occurs at one of the trapping locations over a five year period? Third, how common $V$. germanica is in traps at different parts of Finland?

\section{Material and methods}

\subsection{Traps}

A beer trap was composed of transparent disposable plastic container ( 0.5 litres) covered with a transparent Petri-dish lid (Fig. 2). A circular opening of $2.5 \mathrm{~cm}$ was made on the upper part of the container to allow wasps to enter. Trap transparency may be important for trapping efficiency; otherwise wasps can easily find their way out through the opening. Four litres of trapping liquid was needed for 20 traps ( 0.2 litres per trap). Trapping liquid was made from $25 \mathrm{~g}$ of fresh 


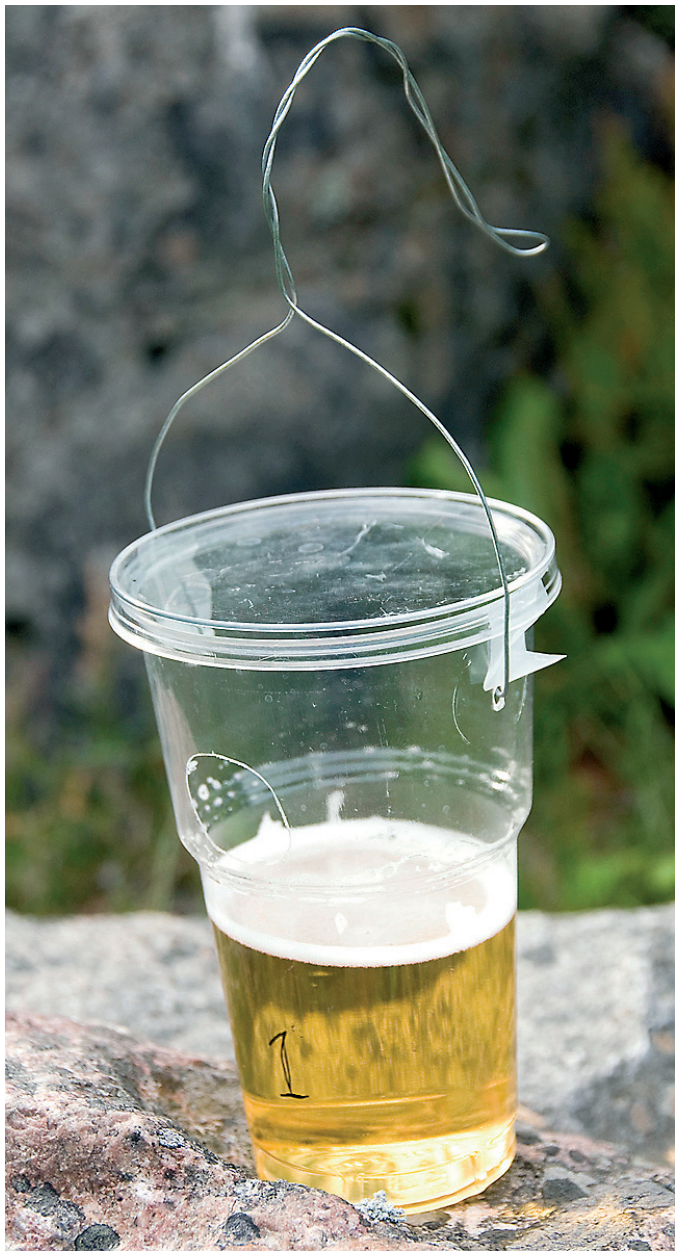

Fig. 2. Beer trap type. Traps are made from transparent plastic containers with a hole in upper side, a transparent Petri-dish cover and steel wire for hanging the trap. Photo: J. Sorvari.

yeast and 5 tablespoons of brown sugar mixed with four litres of lager beer (alcohol 4.7\%-vol.). Using steel wire, the traps were hung on trees and bushes at heights of one to four metres above the ground.

\subsection{Study design}

Trapping was conducted in four different regions in Finland; Turku (southwest), Helsinki (south), Kuopio (central), and Kevo (north; for locations see Fig. 1). In Turku (SW), two different sets of traps were used (i.e. Turku $1 \& 2$ ). A series of
Turku 1 traps was located along the river Aurajoki (east of the city centre, ETRS89/ WGS84 coordinates: N60.465 ${ }^{\circ}$ E $22.293^{\circ} ; 10$ $25 \mathrm{~m}$ a.s.1.). The Turku 2 trap series spread through the town from Mälikkälä in the northwest to Lauste in the southeast (Turku city centre: N60.451 ${ }^{\circ}$ : E22.267 $; 10-40 \mathrm{~m}$ a.s.1.). The Helsinki trap series was located from Hietaniemi in the city centre to Kontula in the northeast (Helsinki: $\mathrm{N} 60.170^{\circ}$ : E24.938 $; 10-50 \mathrm{~m}$ a.s.1.).The Kuopio trap series was located around the city centre of Kuopio (from Jynkkä in the south to Julkula in the north, Kuopio city centre: N62.892 ${ }^{\circ}$ : $27.678^{\circ} ; 40-120$ m a.s.1.). The Kevo trap series was located northeast from the Kevo Subarctic Research Station (University of Turku) along the river valley of Gidešjohka (Kidisjoki) in Utsjoki, Lapland (N69.781 ${ }^{\circ}$ : E27.023 ${ }^{\circ}$; 90 $210 \mathrm{~m}$ a.s.1.). Each trap series consisted of 20 spatially separate traps. The minimum distance between the closest pairs of traps was approximately $200 \mathrm{~m}$. In all locations, traps were located in bushy ecotones between open areas in forests or parks.

The Turku 1 trap series was repeated in the same locations on the same trees and bushes over five consecutive years (2008-2012) during the first three weeks in August, with trapping occurring for a one week period each time. The trapping periods for the other sites were Kevo: 10.16.VII, Kuopio: 2.-9.VIII, Turku 1 \& 2: 7.14.VIII and Helsinki: 8.-15. VIII. The traps were always presented for seven days in each location: for longer periods more attractant would have been needed. The weather was typical warm late summer weather with some showers but without the rain lasting for an entire day. Kevo was an exception to this with moderately cold weather (details below).

\subsection{Statistical methods}

The five year data of the Turku 1 trap series was analysed with a repeated measures generalized linear model using trap as a repeated subject (five years with same traps in same locations) in the models. While the data in other locations was analysed similarly, it was done without a repeated factor (traps used only during one year). The 
Table 1. Summary of the catch of social wasp species in beer traps. For each species, number of individuals caught, mean number of individuals per trap (in parentheses) and percentage of traps occupied by the species $(\%)$ are presented. $V v u l=$ Vespula vulgaris, $V g e r=V$. germanica, $V r u f=V . r u f a$, Dmed $=$ Dolichovespula media, Dsax $=D$. saxonica, Dnor $=$ D. norwegica.

\begin{tabular}{llllllll}
\hline Traps & Date \& year & Vvul & Vger & Vruf & Dmed & Dsax & Dnor \\
\hline Turku 1 & 13.-20.VIII. & $208(10.4)$ & $296(14.8)$ & $1(0.05)$ & - & - & - \\
& 2008 & $100 \%$ & $90 \%$ & $5 \%$ & - & - & - \\
Turku 1 & 1.-8.VIII. & $45(2.25)$ & $17(0.85)$ & $3(0.15)$ & - & - & - \\
& 2009 & $90 \%$ & $40 \%$ & $15 \%$ & - & - & - \\
Turku 1 & 30.VII-6.VIII. & $429(21.45)$ & $132(6.6)$ & - & $39(1.95)$ & $2(0.1)$ & - \\
& 2010 & $100 \%$ & $95 \%$ & - & $65 \%$ & $10 \%$ & - \\
Turku 1 & 4.-11.VIII. & $73(3.65)$ & $6(0.3)$ & $2(0.1)$ & $37(1.85)$ & $1(0.05)$ & - \\
& 2011 & $95 \%$ & $25 \%$ & $5 \%$ & $75 \%$ & $5 \%$ & - \\
Turku 1 & $7 .-14$. VIII. & $189(9.45)$ & $181(9.05)$ & - & $50(2.5)$ & $2(0.1)$ & - \\
& 2012 & $100 \%$ & $100 \%$ & - & $65 \%$ & $10 \%$ & - \\
Turku 2 & $7 .-14$. VIII. & $123(6.15)$ & $18(0.9)$ & $1(0.5)$ & $12(0.6)$ & - & - \\
& 2012 & $100 \%$ & $30 \%$ & $5 \%$ & $35 \%$ & - & - \\
Helsinki & 8.-15.VIII. & $104(5.2)$ & $3(0.15)$ & - & $5(0.25)$ & - & - \\
& 2012 & $90 \%$ & $10 \%$ & - & $20 \%$ & - & - \\
Kuopio & $2 .-9$. VIII. & $149(7.45)$ & - & - & $9(0.45)$ & $5(0.25)$ & - \\
& 2012 & $85 \%$ & - & - & $35 \%$ & $20 \%$ & - \\
Kevo & $10 .-16$. VII. & - & - & - & $1(0.05)$ & - & $1(0.05)$ \\
& 2012 & - & - & - & $5 \%$ & - & $5 \%$ \\
\hline
\end{tabular}

number of individuals per trap was analysed using the number of individuals of each species as a dependent variable with Poisson distribution (counts) and log link-function. Trap occupancy rates were analysed using the presence of species as a binomial variable $(0=$ not found in trap, $1=$ found) with a logit link-function. Multiple comparisons were made with step-down sequential Bonferroni correction tests ( $p$-values ranked from smallest to largest and sequentially removing the most significant pair-wise). The analyses were performed using the procedure GENMOD in SAS 9.2 statistical software (SAS institute, Cary, NC, USA).

\section{Results}

\subsection{Species caught}

The beer traps caught a total of 2,144 social wasp workers belonging to six species: Vespula vulgaris Linnaeus, 1758, V. germanica (Fabricius, 1793), V. rufa Linnaeus, 1758, Dolichovespula media (Retzius, 1783), D. norwegica (Fabricius, 1781), and D. saxonica (Fabricius, 1793) (Table 1). All species, except $D$. norwe- gica, were present in the combined five year catch of the Turku 1 trap series. Turku 2 lacked $D$. norwegica and $D$. saxonica, while the Helsinki trap series lacked $V$. rufa, D. norwegica, and $D$. saxonica, and the Kuopio series lacked $V$. germanica, V. rufa, and D. norwegica. By comparison, the Kevo trap series lacked all but D. media and $D$. norwegica. Although the only species found in all of the trapping locations was D. media, it was not caught in the Turku 1 trap series in the years 2008 and 2009. While $V$. germanica was present in Turku 1 (in all five years), Turku 2 and Helsinki trap series, it did not occur in the Kuopio and Kevo trap series. In addition to workers, 11 males of $V$. vulgaris and 1 male of $V$. germanica were found in the traps in 2008. In other years and trap series, all individuals were workers. The males $(N=12)$ were not used in further analyses.

\subsection{Turku 1 trap series}

The number of individuals caught differed between species (repeated generalized linear model: $\left.d f=4, \chi^{2}=627.83, p<0.0001\right)$. The numbers of individuals differed between all species 

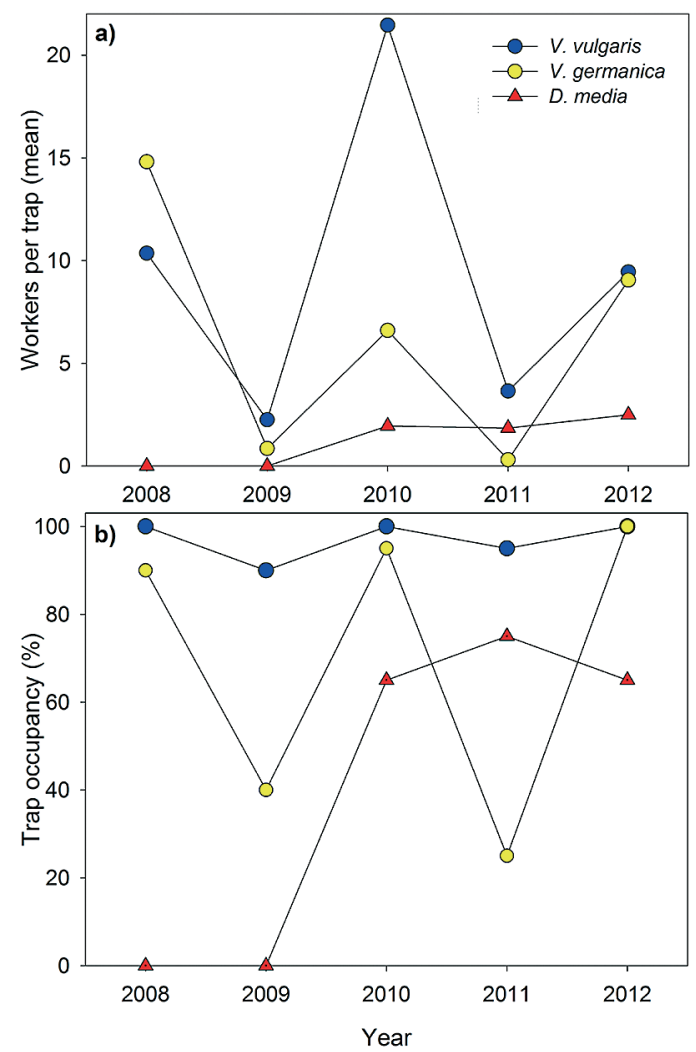

Fig. 3. Variations in numbers and occupancy rates of social wasps in Turku 1 trap series among years 2008-2012. - a. Mean numbers of individuals per trap. - b. Occupancy rates.

pairs except between $V$. rufa vs. D. saxonica (multiple comparisons with sequential Bonferroni corrections, $V$. rufa vs. D. saxonica: $p=$ 0.78 ; all other species pairs: $p<0.05)$. The number of individuals caught varied differently between species and years (repeated generalized linear model, interaction term year $\times$ species: $d f=$ $5, \chi^{2}=732.51, p<0.0001$; Fig. 3a for $V$. vulgaris, $V$. germanica, and $D$. media). The trap occupancy rate (probability of occurrence of the species in traps) differed between the species (repeated generalized linear mixed model: $d f=4, \chi^{2}=227.73, p$ $<0.0001)$. The trap occupancy rate differed between all other species pairs except between $V$. rufa vs. D. saxonica (multiple comparisons with sequential Bonferroni corrections, $V$. rufa vs. $D$. saxonica: $p>0.99$; other species pairs: $p<0.05$ ). The similarity in numbers of individuals in traps and trap occupancy rates between $V$. rufa and $D$. saxonica was apparently due to the very low numbers of both species in the traps. The trap occupancy rates varied between species and years (repeated generalized linear model, interaction term year $\times$ species: $d f=5, \chi^{2}=231.58, p<$ 0.0001 ; Fig. 3 b for $V$. vulgaris, $V$. germanica, and D. media).

The data from year 2012 was analysed separately to compare Turku 1 with other locations. The number of individuals caught differed between species (generalized linear model: $d f=3$, $\left.\chi^{2}=113.64, p<0.0001\right)$. The numbers of individuals differed between all other species pairs except between $V$. vulgaris vs. $V$. germanica (multiple comparisons with sequential Bonferroni corrections, $V$. vulgaris vs. $V$. germanica: $p=0.68$; other species pairs: $p<0.05$ ). The trap occupancy rates of $V$. vulgaris and $V$. germanica were both $100 \%$, whereas it was $65 \%$ in D. media and $10 \%$ in $D$. saxonica. The rates differed between species (generalized linear model: $d f=3, \chi^{2}=10.23$, $p=0.017)$. The trap occupancy rate differed between all other species pairs except between $V$. vulgaris vs. $V$. germanica (multiple comparisons with sequential Bonferroni corrections, $V$. vulgaris vs. $V$. germanica: $p>0.99$; other species pairs: $p<0.05$ ).

\subsection{Turku 2 trap series}

The number of individuals caught differed between species (generalized linear model: $d f=3$, $\left.\chi^{2}=125.19, p<0.0001\right)$. The numbers of individuals differed between all species pairs except between $V$. germanica vs. D. media (multiple comparisons with sequential Bonferroni corrections, $V$. germanica vs. D. media: $p=0.28$; other species pairs: $p<0.05)$. The trap occupancy rate differed between the species (generalized linear model: $d f$ $\left.=2, \chi^{2}=676.49, p<0.0001\right)$. The occupancy rate of $V$. vulgaris $(100 \%)$ was significantly higher than in the other species having occupancy rates from five to $35 \%$, which did not differ significantly from each other's (sequential Bonferroni corrected pair-wise differences, $V$. vulgaris $v$ s. others: $p$-values $<0.05$; other species pairs: $p$-values $>0.05)$. 
Fig. 4. Mean numbers of social wasp individuals per trap in Turku 1, Turku 2, Helsinki and Kuopio trap series in summer 2012. Symbols represent estimated marginal means and asymmetric $95 \%$ confidence limits computed with a generalized linear model. A different letter above symbols between the same species indicates statistically significant differences between trap series after a sequential Bonferroni correction.

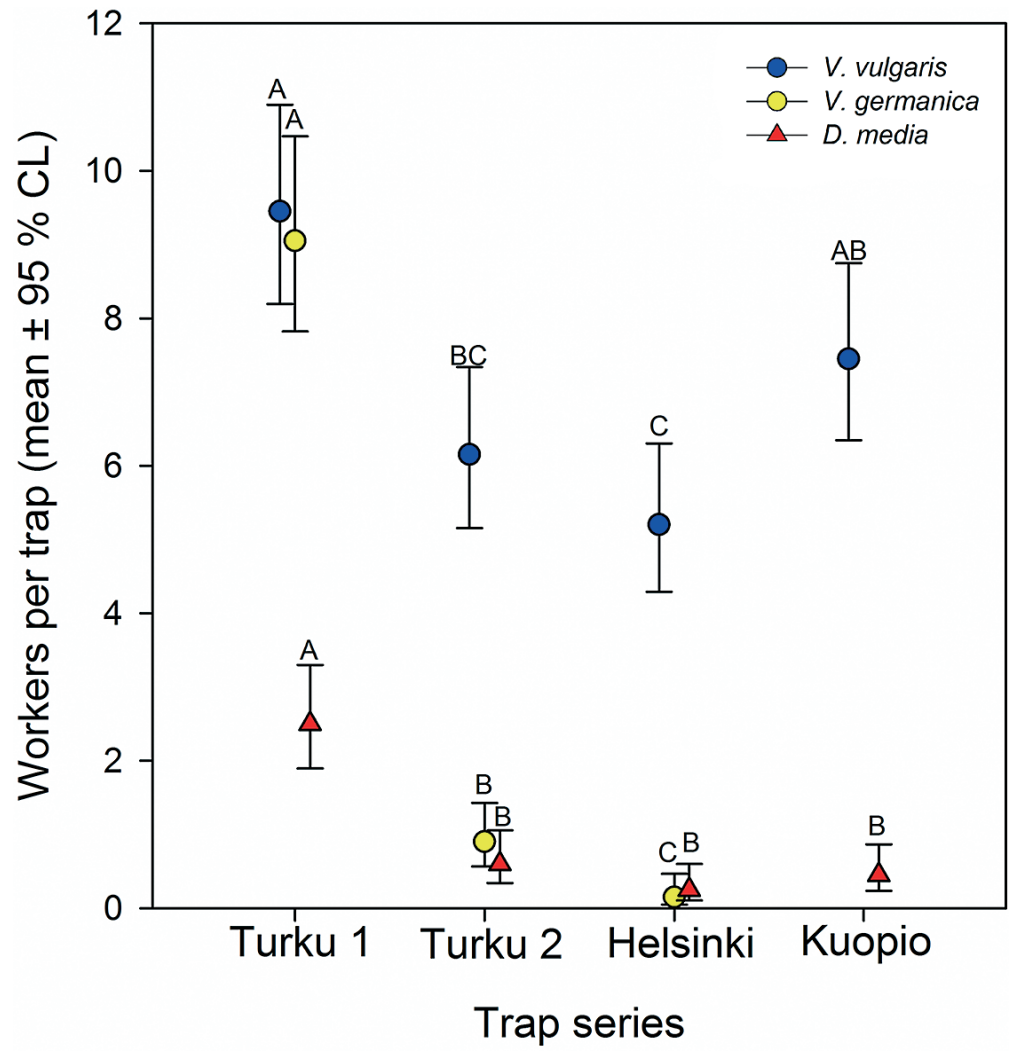

\subsection{Helsinki trap series}

The number of individuals caught differed between species (generalized linear model: $d f=2$, $\left.\chi^{2}=77.82, p<0.0001\right)$. The numbers of individuals were significantly higher in $V$. vulgaris than in the other species, whereas the number of individuals did not differ between the others, i.e., $V$. germanica and $D$. media (multiple comparisons with sequential Bonferroni corrections, $V$. vulgaris vs. D. media and $V$. vulgaris vs. V. germanica: both $p<0.05 ; V$. germanica vs. D. media: $p=0.48)$. The trap occupancy rate differed between the species (generalized linear model: $d f=$ $\left.2, \chi^{2}=20.64, p<0.0001\right)$. The occupancy rate of V. vulgaris was $90 \%$ (18 out of 20 traps) and was significantly higher than in $V$. germanica and $D$. media, which did not differ significantly from each other (occupancy rates 10 and 20\%, respectively; multiple comparisons with sequential Bonferroni corrections, V. vulgaris vs. D. media and $V$. vulgaris vs. $V$. germanica: both $p<0.05, V$. germanica vs. D. media: $p=0.38$ ).

\subsection{Kuopio trap series}

The number of individuals caught differed between species (generalized linear model: $d f=2$, $\left.\chi^{2}=112.32, p<0.0001\right)$. The numbers of individuals were significantly higher for $V$. vulgaris than for other species, whereas the number of individuals did not differ between the others, $D$. media and $D$. saxonica (multiple comparisons with sequential Bonferroni corrections, V. vulgaris vs. D. media and $V$. vulgaris vs. D. saxonica: both $p<$ $0.05 ;$ D. media vs. D. saxonica: $p=0.09$ ). The trap occupancy rate differed between the species (generalized linear model: $d f=2, \chi^{2}=15.20, p=$ $0.0005)$. The occupancy rate of $V$. vulgaris was $85 \%$ (17 out of 20 traps) and was significantly higher than in D. media and D. saxonica, which did not differ significantly from each other (occupancy rates 35 and $20 \%$, respectively; multiple comparisons with sequential Bonferroni corrections, $V$. vulgaris vs. D. media and $V$. vulgaris vs. D. saxonica: both $p<0.05 ; D$. media vs. $D$. saxonica: $p=0.13$ ). 


\subsection{Kevo trap series}

The June-July mean temperature was about $1^{\circ} \mathrm{C}$ colder than usually in Kevo region in Lappland in summer 2012 (Finnish Meteorological Institute 2013). Possibly due to the cool weather only two wasp individuals were caught (one D. media and one $D$. norwegica). Therefore, further analyses were unnecessary and data from Kevo is not used in analyses of between sites comparisons. The small catch, however, was surprisingly interesting since the D. media individual caught was the northernmost record of the species (distribution in, e.g., Pekkarinen \& Huldén 1995, Witt 2009, Douwes et al. 2012).

\subsection{Between sites comparison}

Of the wasp species $V$. vulgaris, $V$. germanica, and $D$. media were the most common species contributing together over $99.1 \%$ of the individuals ( $V$. vulgaris: $61.5 \%$; V. germanica: $30.5 \% ; D$. media: $7.1 \%$ ) and the results remain almost the same when data from years 2008-2011 (of Turku 1) are removed: the species triplet constitutes $98.9 \%$ of the individuals ( $V$. vulgaris: $66.2 \% ; V$. germanica: $23.7 \%$; D. media: $9.0 \%$ ). Because these three species were clearly the most abundant, their relative abundance was compared between the sites (excluding Kevo).

The trap series (locations) differed significantly for all of the three most abundant species (generalized linear models, $V$. vulgaris: $d f=3, \chi^{2}$ $=28.20, p<0.0001 ; V$. germanica: $d f=3, \chi^{2}=$ 131.97, $p<0.0001 ; D$. media: $d f=3, \chi^{2}=51.86, p$ $<0.0001$; Fig. 4). The number of $V$. vulgaris workers was highest in Turku 1 trap series, followed by Kuopio, Turku 2 and Helsinki, respectively (Fig. 4). The number of $V$. germanica workers was highest in Turku 1 followed by Turku 2 and Helsinki (not in Kuopio). The number of D. media workers was also highest in Turku 1, followed by Turku 2, Kuopio and Helsinki.

\section{Discussion}

\subsection{General}

The species composition of the present study closely resembles those of previous beer-trapping studies made by other researchers in Europe (Dvořák 2007, Dvořák \& Roberts 2007, Roberts \& Dvořák 2008). The only real difference is the absence of the European hornet Vespa crabro Linnaeus, 1758 which was very commonly found in other studies. In addition, the catches of $V$. rufa and Dolichovespula species other than D. media were similarly marginal in those beer trapping studies. Although beer trapping cannot be used to monitor populations of all social wasp species, it is useful in monitoring the four species ( $V$. vulgaris, $V$. germanica, D. media, and V. crabro). While $V$. crabro has recently been found in several places in southern Finland (Teräs et al. 2003) its absence in the beer traps may indicate its rareness around cities, possibly because it is strongly associated with forests (Dvořák 2007, Roberts \& Dvořák 2008).

Yearly fluctuations in the abundance of $V$. vulgaris and $V$. germanica may be caused by weather conditions, especially those of spring (and perhaps summer and autumn) or by endogenous factors affecting queen quality or survival (Archer 1985). It has been observed that when the number of colony founding queens is high in the spring, the following summer shows either a decreased or at least, no increase in the number of workers (Archer 1985). This is explained by the poorer quality of mass-produced queens and/or by competition for nesting places, resulting in a high mortality of queens due to fighting during frequent colony usurpations (Archer 1985). Warm spring weather has been shown to shift the phenology of $V$. germanica earlier (Tryjanowski et al. 2010). Therefore, the colonies may be bigger in summers after a warm spring due to shifted phenology. In addition, parasites, pathogens and predators may also cause variations in wasp abundances (Spradbery 1973). Migration of queens can be important, especially in $D$. media (see Fig. 3b), which undergo mass migrations occasionally (see Mikkola et al. 2007). The mass migrations of queens are possibly caused by unfavourable weather conditions. In early summer 
2007, D. media displayed a mass migration in southern Finland, which resulted in a population crash at the end of the summer (Mikkola et al. 2007). The absence of D. media in traps in both 2008 and 2009 (Turku 1) may have been caused by the observed population crash.

\subsection{Vespula germanica}

Bearing in mind the recent colonization of continental Finland by $V$. germanica, it was surprisingly common in southern Finland. It has apparently shifted its range rapidly northwards, likely due to climate change. Climate driven range shifts have been observed earlier in butterflies (Parmesan et al. 1999, Crozier 2003, Pöyry et al. 2009). The northernmost record of $D$. media found in this study may indicate that other social wasps may also respond to climate change with a similar northward shift.

According to the results of beer trapping of this study, $V$. germanica has been on average the second most common social wasp in the Turku region (SW-Finland) since the summer 2008, second only to its sister species $V$. vulgaris. Thus far, the northernmost records of breeding $V$. germanica colonies (indicated by the presence of foraging workers) in western Finland are from Rauma (N61.129: E21.505 ; J. Sorvari, summer 2012) and in eastern Finland from Imatra (N61.198 : E28.769 ; J. Jantunen, pers, comm. \& photographs, summer 2011) (see Fig. 1).

Vespula germanica has been accidentally carried outside its native range by human activities and has become a serious invasive species in Australia, New Zealand, Argentina, Chile, Canada, USA, South Africa, Malta, Canary Islands (Spain) and Madeira (Portugal) (Spradbery \& Dvořák 2010). It has also been introduced to Iceland but is not considered there as an invasive species (Spradbery \& Dvořák 2010). This species has several ecological characters that make it potentially a highly invasive species, e.g., it has wide native range, it is highly adaptable to different environments, it is tolerant to anthropogenic disturbance and it has fast colony growth and a broad spectrum of diet (Spradbery \& Dvořák 2010). These ecological characters are also likely to affect its successful and rapid range expansion in southern Finland.
Further studies and additional locations are needed to monitor the actual range of the species in Finland. In addition to $V$. germanica, the spread of $V$. crabro in its northern limits could likely be monitored with beer trapping.

Acknowledgements. Two anonymous referees gave valuable comments on the previous draft of the manuscript. $\mathrm{T}$. Andersson (Kevo Subarctic Research Station, University of Turku) carried out the beer trapping in Kevo and gave comments on the manuscript. In addition, I'm grateful for J. Jantunen, R. Molini, J. Paukkunen, J. Pöyry, I. Teräs and $\mathrm{S}$. Väänänen for their information concerning observations of $V$. germanica in Finland. The study was funded by Kone foundation and Emil Aaltonen Foundation.

\section{References}

Archer, M. E. 1985: Population dynamics of the social wasps Vespula vulgaris and Vespula germanica in England. - Journal of Animal Ecology 54: 473-485.

Crozier, L. 2003: Winter warming facilitates range expansion: cold tolerance of the butterfly Atalopedes campestris. - Oecologia 135: 648-656.

Douwes, P., Abenius, J., Cederberg, B., Wahlstedt, U., Hall, K., Starkenberg, M., Reisborg, C. \& Östman, T. 2012: Nationalnyckeln till Sveriges flora och fauna. Steklar: Myror-getingar. Hymenoptera: FormicidaeVespidae. - ArtDatabanken, SLU, Uppsala. 382 pp.

Dvořák, L. 2007: Social wasps (Hymenoptera: Vespidae) trapped with beer in European forest ecosystems. Acta Musei Moraviae, Scientiae biologicae (Brno) 92: 181-204.

Dvořák, L. \& Landolt, P. J. 2006: Social wasps trapped in the Czech Republic with syrup and fermented fruit and comparison with similar studies (Hymenoptera Vespidae). - Bulletin of Insectology 59 (2): 115-120.

Dvořák, L. \& Roberts, S. P. M. 2007: Results of wasp beer trapping 2006 in the UK. - BWARS Newsletter Spring 2007: 13-18.

Eeva, T., Sorvari, J. \& Rinne, V. 2006: A likely German wasp (Vespula germanica) breeding colony in continental Finland. - Sahlbergia 11: 53-54.

Finnish Meteorological Institute 2012: Kuukausitilastot. [www document] URL http://ilmatieteenlaitos.fi/kuukausitilastot. (site visited 14 January 2013).

Johansson, K. \& Pekkarinen, A. 2000: Saksanampiainen (Vespula germanica) löytynyt talvella Turusta (Hymenoptera, Vespidae). [Vespula germanica found in the winter in southwestern Finland]. - Sahlbergia 5: 49.

Kurzenko, N. V. 1982: Vespula germanica (Fabricius, 1793). - Akademy Nauk USSR, Atlas Karty 126178: 22.

Mikkola, K., Kaila, L., Rantala, M., Segersvärd, P. \& Vuolanto, S. 2007: Edeltävän hellekesän entomologisia 
seurausilmiöitä alkukesällä 2007 Suomessa ja Latviassa (Odonata, Heteroptera, Hymenoptera, Lepidoptera ja Coleoptera) [Some entomological consequences of the exceptionally xerothermic summer 2006 shown in early season of 2007 in Finland and Latvia (Odonata, Heteroptera, Hymenoptera, Lepidoptera and Coleoptera)]. - Sahlbergia 13: 26-33.

Parmesan, C., Ryrholm, N., Stefanescu, C., Hill, J. K., Thomas, C. D., Descimon, H., Huntley, B., Kaila, L., Kullberg, J., Tammaru, T., Tennent, W. J., Thomas, J. A. \& Warren, M. 1999; Poleward shifts in geographical ranges of butterfly species associated with regional warming. - Nature 399: 579-583.

Pekkarinen, A. \& Huldén, L. 1995: Distribution and phenology of the Vespinae and Polistinae species in eastern Fennoscandia (Hymenoptera: Vespidae) 1. Sahlbergia 2: 99-111.

Pöyry, J., Luoto, M., Heikkinen, R. K., Kuussaari, M. \& Saarinen, K. 2009: Species traits explain recent range shifts of Finnish butterflies. - Global Change Biology 15: 732-743.

Roberts, S. P. M. \& Dvořák, L. 2008: Results of wasp beer trapping 2007 in the UK and a comparison between open and wooded habitats. - BWARS Newsletter Spring 2008: 14-19.

Seath, C. J. 1999: Wasp (Hymenoptera: Vespidae) trapping with carbohydrates. - In: Robinson. W. H, Rettich, F. \& Rambo, G. W. (eds.), Proceedings of the 3rd International Conference of Urban Pests: 275-280.
Söderman, G. 1999: Diversity of pollinator communities in Eastern Fennoscandia and Eastern Baltics: Results from pilot monitoring with Yellow traps in 19971998. — The Finnish Environment 355. 74 pp.

Söderman, G., Leinonen, R. \& Lundsten, K.-E. 1997: Monitoring bumblebees and other pollinator insects. Mimeograph Series of the Finnish Environment Institute $58.43 \mathrm{pp}$.

Spradbery, J. P. 1973: Wasps: An account of the biology and natural history of solitary and social wasps. University of Washington Press, Seatle, USA. 408 pp. Spradbery, P. \& Dvořak, L. 2010: Datasheet on Vespula germanica, Invasive Species Compendium, CABI Wallingford, UK. 21pp. [www document] URL www.cabi.org/isc (site visited 25 January 2013).

Teräs, I., Jantunen, J., Pekkarinen, A., Saarinen, K. \& Sorjonen, J. 2003: Herhiläisen uusi tuleminen. — Luonnon Tutkija 107(5): 168-176.

Tryjanowski, P., Pawlikowski, T., Pawlikowski, K., Banaszak-Cibicka, W. \& Sparks, T. H. 2010: Does climate influence phenological trends in social wasps (Hymenoptera: Vespinae) in Poland? - European Journal of Entomology 107: 203-208.

Wegner, G. S. \& Jordan, K. K. 2005: Comparison of three liquid lures for trapping social wasps (Hymenoptera: Vespidae). - Journal of Economic Entomology 98 (3): 664-666.

Witt, R. 2009: Wespen. — Vademecum-Verlag, Oldenburg. $400 \mathrm{pp}$. 